\title{
The Corrosion Resistance of Nickel Electrocomposite Coating Containing $\mathrm{BaFe}_{12} \mathrm{O}_{19}$ Particles
}

\author{
S. T. Aruna, G. Savitha, Jyothi Shedthi, and V. K. William Grips \\ National Aerospace Laboratories, Council of Scientific and Industrial Research, Post Bag No. 1779, Bangalore 560 017, India \\ Correspondence should be addressed to S. T. Aruna; staruna194@gmail.com
}

Received 20 November 2012; Accepted 14 January 2013

Academic Editors: G. El Mahdy, C. Gu, H. Miao, and C. Valentini

Copyright (C) 2013 S. T. Aruna et al. This is an open access article distributed under the Creative Commons Attribution License, which permits unrestricted use, distribution, and reproduction in any medium, provided the original work is properly cited.

\begin{abstract}
Electroplating composite coating is an effective method to prepare composite coating through the codeposition of metallic, nonmetallic, or polymer particles with metal to improve properties such as corrosion resistance, hardness, and wear performance. This paper reports the synthesis of a novel $\mathrm{Ni}-\mathrm{BaFe}_{12} \mathrm{O}_{19}$ magnetic nanocomposite coating exhibiting improved corrosion resistance. In the present paper, $\mathrm{BaFe}_{12} \mathrm{O}_{19}$ particles were synthesized by a single-step solution combustion method and characterized for phase, particle size, and morphology. These particles were incorporated in a nickel metal matrix, and the properties of the coatings like nanohardness and corrosion resistance were investigated. The coating microstructure was also studied using field emission scanning electron microscope. A Vickers hardness of $777 \mathrm{HV}$ was exhibited by $\mathrm{Ni}-\mathrm{BaFe}_{12} \mathrm{O}_{19}$, and plain Ni coating exhibited a hardness of $517 \mathrm{HV}$. The $\mathrm{Ni}-\mathrm{BaFe}_{12} \mathrm{O}_{19}$ composite coating exhibited improved corrosion resistance compared to plain Ni coating with an $i_{\text {corr }}$ value of $0.034 \mu \mathrm{A} / \mathrm{cm}^{2}$ compared to $0.361 \mu \mathrm{A} / \mathrm{cm}^{2}$ for plain Ni. The Ni-BaFe ${ }_{12} \mathrm{O}_{19}$ coating also exhibited higher charge transfer and polarization resistance compared to plain Ni coating.
\end{abstract}

\section{Introduction}

In recent years, there is an increased interest in the synthesis and properties of particle reinforced metal matrix nanocomposite coatings with grain size of both matrix and dispersed particles less than $100 \mathrm{~nm}$ [1]. Particle-reinforced metal matrix composite (MMC) coatings have been widely used in various engineering applications due to their excellent mechanical, wear, and corrosion resistant properties compared to their components [2]. In composite materials, the metal matrix properties are modified by the addition of various insoluble substances like hard oxides $\left(\mathrm{Al}_{2} \mathrm{O}_{3}\right.$, $\mathrm{ZrO}_{2}, \mathrm{SiO}_{2}, \mathrm{TiO}_{2}$, and $\mathrm{CeO}_{2}$ ); carbides ( $\mathrm{SiC}$ and $\mathrm{WC}$ ); diamond or solid lubricants (graphite, $\mathrm{MoS}_{2}$, or PTFE) [2, 3]. Electrocodeposition is a coating protective technique which consists of introducing homogeneously dispersing inert particles of a different material in the metal matrix; this two-phase coating improves corrosion, wear, and mechanical resistance. The improvement of these properties depends on the combination of both particles and metal matrix. This method has the following advantages like low cost, low temperature and single-step process without additional thermal treatment [4]. The application of magnetic particles in electrodeposited composite coatings is less explored. Barium ferrite thin film media are attractive candidates for highdensity overcoat free magnetic recording due to their large uniaxial anisotropy, high chemical stability, and corrosion resistance [5]. Thin films and micromagnets arrays of a composite matrix consisting of magnetic particles and a ferromagnetic alloy have been fabricated based on magnetic composite electroplating. Guan and Nelson have reported the fabrication of arrays of $\mathrm{CoNiP}-\mathrm{BaFe}_{12} \mathrm{O}_{19}$ magnets with a variety of dimensions and features as small as $8 \mu \mathrm{m}$ [6]. $\mathrm{Qu}$ and Jiao also reported the fabrication of CoNiMnP$\mathrm{BaFe}_{12} \mathrm{O}_{19}$ magnetic composite coating by electrodeposition for applications in microelectromechanical systems actuators. This coating exhibited a maximum magnetic energy density of $17.68 \mathrm{kJm}^{-3}$ and maximum coercivity of $1342 \mathrm{Oe}$ [7]. However, to the best of our knowledge, there are no reports on the application of barium hexaferrite particles for improving the corrosion resistance of electrodeposited Ni-metal matrix composites. The main aim of the present 
work is to prepare barium hexaferrite magnetic particles and incorporate them in $\mathrm{Ni}$-metal matrix and study the corrosion resistance and microstructure of the composite coating.

\section{Experimental}

2.1. Preparation and Characterization of Barium Hexaferrite Powder. The solution combustion method is a very versatile technique that has been used for the preparation of magnetic oxides and in particular ferrites [8]. Barium hexaferrite powder was prepared by the solution combustion method as follows: an aqueous redox mixture containing stoichiometric amounts of barium nitrate $(5.39 \mathrm{~g})$, ferric nitrate $(100 \mathrm{~g})$, and $46.33 \mathrm{~g}$ of oxalyl dihydrazide $(\mathrm{ODH})$ was dissolved in minimum amounts of water and transferred into an alumina crucible and placed in a muffle furnace. The oxidizer-to-fuel ratio was maintained as unity. The temperature of the furnace was raised to $450^{\circ} \mathrm{C}$ and then switched off. The solution boils, undergoes frothing, and undergoes smoldering type combustion with low intensity sparks. This is followed by the evolution of copious amounts of gases and results in a brown voluminous mass. The obtained brown voluminous mass was the hard magnetic barium hexaferrite particles (Figure 1(a)). The as-prepared powder was magnetic in nature (Figure 1(b)).

Assuming complete combustion, the theoretical equation for the formation of barium ferrite using ODH can be written as follows:

$$
\begin{aligned}
& \mathrm{Ba}\left(\mathrm{NO}_{3}\right)_{2(\mathrm{aq})}+12 \mathrm{Fe}\left(\mathrm{NO}_{3}\right)_{3(\mathrm{aq})}+19 \mathrm{C}_{2} \mathrm{H}_{6} \mathrm{~N}_{4} \mathrm{O}_{2} \\
& \longrightarrow \mathrm{BaFe}_{12} \mathrm{O}_{19}+38 \mathrm{CO}_{2(\mathrm{~g})}+57 \mathrm{H}_{2} \mathrm{O}+57 \mathrm{~N}_{2}
\end{aligned}
$$

For every mole of $\mathrm{BaFe}_{12} \mathrm{O}_{19}$ formed 152 moles of gases were evolved. The powder was characterized by powder X-ray diffractometer (Bruker D8, Advance), particle size analyzer (Mastersizer 2000, Malvern Instruments), and field emission scanning electron microscope (FESEM, Carl Zeiss Supra 40 VP).

2.2. Preparation of $\mathrm{Ni}-\mathrm{BaFe}{ }_{12} \mathrm{O}_{19}$ Composite Coatings. Nickel sulfamate plating bath was prepared by mixing $300 \mathrm{~g} \mathrm{~L}^{-1}$ of nickel sulfamate solution (50 $\mathrm{g}$ of nickel per liter), $10 \mathrm{~g} \mathrm{~L}^{-1}$ of nickel chloride, $30 \mathrm{~g} \mathrm{~L}^{-1}$ boric acid, and $0.2 \mathrm{~g} \mathrm{~L}^{-1}$ of sodium lauryl sulfate. The Ni-sulfamate plating bath (approximately $200 \mathrm{~mL}$ ) containing $\mathrm{BaFe}_{12} \mathrm{O}_{19}$ particles $(5 \mathrm{~g} / \mathrm{L})$ was taken in a glass beaker and was mechanically stirred overnight. For higher bath loadings, the electrolyte bath was saturated with powders because of its very fine nature, and there was no coating formation, and hence $5 \mathrm{~g} / \mathrm{L}$ of barium hexaferrite particles was chosen. During electrodeposition, the bath was held at room temperature, and its $\mathrm{pH}$ was maintained at 4 by the addition of sulfamic acid and basic nickel carbonate. A pure nickel sheet $(2.5 \mathrm{~cm} \times 12 \mathrm{~cm})$ and a brass substrate of the same dimension were used as anode and cathode of respectively. The polished brass substrate of area $2.5 \mathrm{~cm} \times 3.75 \mathrm{~cm}$ was degreased with acetone followed by cathodic cleaning and acid dipping and finally washed with distilled water. In order to ensure uniform dispersion of the powder, the electrolyte bath containing particles was subjected to mechanical agitation for 15 hours before the deposition process, and during electrodeposition the particles were also mechanically stirred at a fixed rpm. The codeposition was carried out at $1.55 \mathrm{Adm}^{-2}$ for $3 \mathrm{~h}$ such that the deposit thickness was approximately $40 \mu \mathrm{m}$ based on Faraday's laws.

\subsection{Characterization of $\mathrm{Ni}-\mathrm{BaFe}_{12} \mathrm{O}_{19}$ Composite Coatings}

2.3.1. XRD, Nanohardness, and Microstructural Studies of $\mathrm{BaFe}_{12} \mathrm{O}_{19}$ Composite Coatings. The XRD patterns of plain $\mathrm{Ni}$ and $\mathrm{Ni}-\mathrm{BaFe}_{12} \mathrm{O}_{19}$ composite coatings electrodeposited at $1.55 \mathrm{~A} \mathrm{dm}^{-2}$ were also recorded. The metallographic specimens for cross-sectional studies were prepared by sandwiching electrodeposited $\mathrm{Ni}-\mathrm{BaFe}_{12} \mathrm{O}_{19}$ brass coupons with a copper backup in a Bakelite matrix followed by mechanical grinding and polishing with $\mathrm{Al}_{2} \mathrm{O}_{3}$ slurry, down to $0.05 \mu \mathrm{m}$. The nanohardness was obtained on electrodeposited $\mathrm{Ni}$ and $\mathrm{Ni}-\mathrm{BaFe}_{12} \mathrm{O}_{19}$ cross-sections using CSM Instruments using the Oliver Pharr method. A Berkovich diamond indenter with $200 \mathrm{mN}$ load was used for the measurements. The surface FESEM images of plain $\mathrm{Ni}$ and $\mathrm{Ni}-\mathrm{BaFe}_{12} \mathrm{O}_{19}$ coatings were also recorded.

2.3.2. Corrosion Studies. Corrosion behavior of $\mathrm{Ni}$ and $\mathrm{Ni}-\mathrm{BaFe}_{12} \mathrm{O}_{19}$ composite coatings electrodeposited at $1.55 \mathrm{~A} \mathrm{dm}^{-2}$ for $45 \mathrm{~min}$ on mild steel coupons was conducted using CHI 604 2D electrochemical workstation. The test was carried out in deaerated $3.5 \mathrm{wt} \%(0.6 \mathrm{M}) \mathrm{NaCl}$ solution $(200 \pm 2 \mathrm{~mL})$ using conventional three-electrode cell equipped with coated brass coupon with an active area of $1 \mathrm{~cm}^{2}$ as working electrode and platinum foil and saturated calomel electrode (SCE) used as counter and reference electrodes, respectively. The reference electrode was connected to a Luggin capillary, and its tip was placed very close to the surface of the working electrode to minimize IR drop. The coupon was immersed in $\mathrm{NaCl}$ solution for an hour in order to establish the open circuit potential (EOCP). Electrochemical Impedance Spectroscopy (EIS) studies were carried out in the frequency range of $100 \mathrm{kHz}-10 \mathrm{mHz}$. The amplitude of applied alternating potential was $10 \mathrm{mV}$ on the EOCP. The impedance data was displayed as Nyquist and Bode plots, respectively. The Nyquist plot is a plot of real $\left(Z^{\prime}\right)$ versus imaginary impedance $\left(Z^{\prime \prime}\right)$. The Bode plot is a plot of $|Z|$ versus frequency and frequency versus phase angle $(\theta)$, where $|Z|$ is the absolute impedance. The acquired data were curve-fitted and analyzed using ZSimpWin program. After EIS measurements, the system was allowed to attain open circuit potential, then the upper and lower potential limits of linear sweep voltammetry were set at $\pm 200 \mathrm{mV}$ with respect to the EOCP. The sweep rate was $1 \mathrm{mV} / \mathrm{s}$. The Tafel plots obtained have been represented as potential versus $\log i$ plot.

The corrosion potential $E_{\text {corr }}$, corrosion current density $i_{\text {corr }}$, and polarization resistance $R_{p}$ were deduced from the 


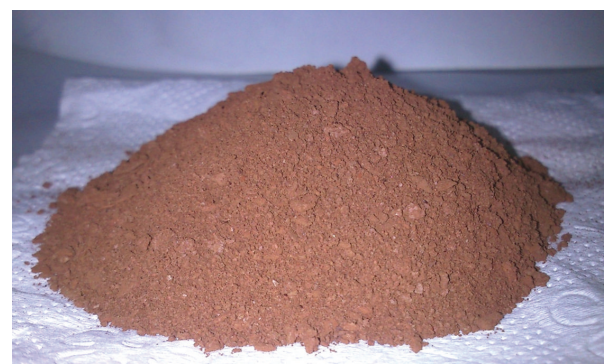

(a)

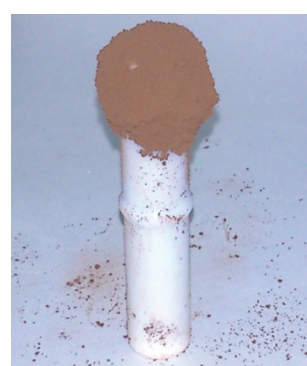

(b)

FIGURE 1: Photographs showing combustion synthesized $\mathrm{BaFe}_{12} \mathrm{O}_{19}$ powder (a) after crushing and (b) attracted to magnetic stirring bar.

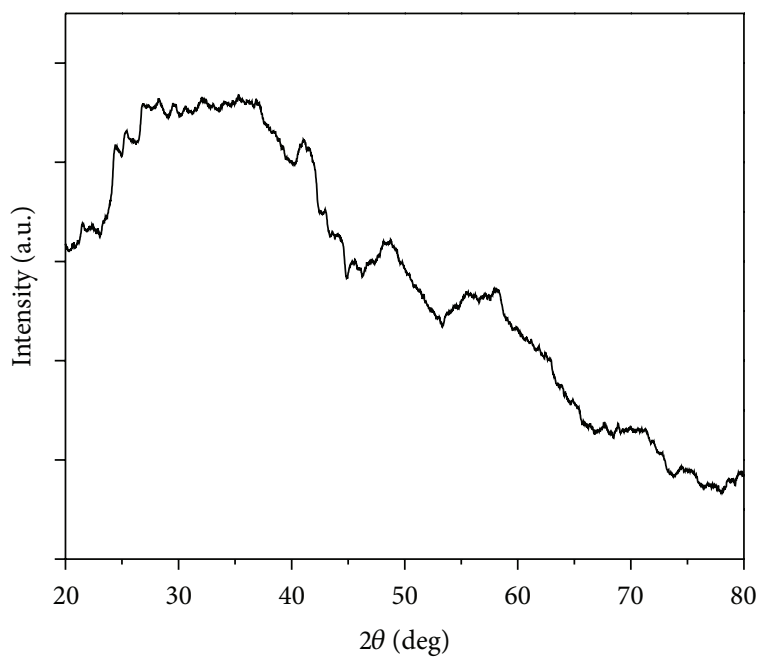

FIgure 2: Powder XRD pattern of as-prepared $\mathrm{BaFe}_{12} \mathrm{O}_{19}$ powder.

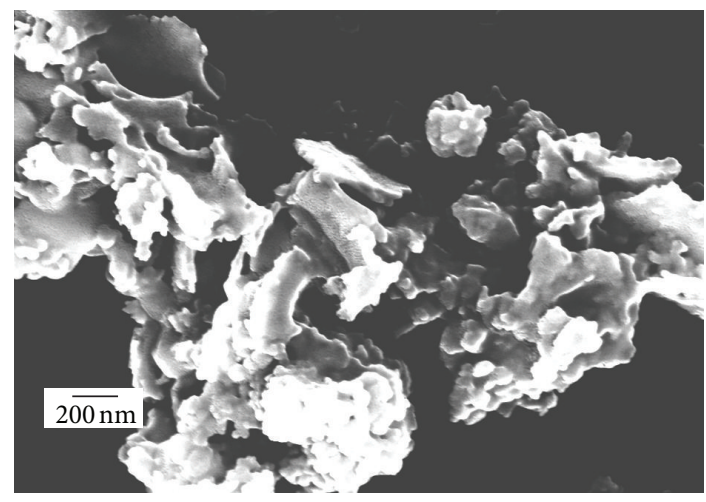

FIGURE 3: Field emission scanning electron microscope image of asprepared barium ferrite particles.

Tafel plot. The polarization resistance was obtained using the Stern-Geary equation:

$$
R_{p}=\left[\frac{b_{a} b_{c}}{2.303\left(b_{a}+b_{c}\right)}\right]\left[\frac{1}{i_{\text {corr }}}\right]
$$

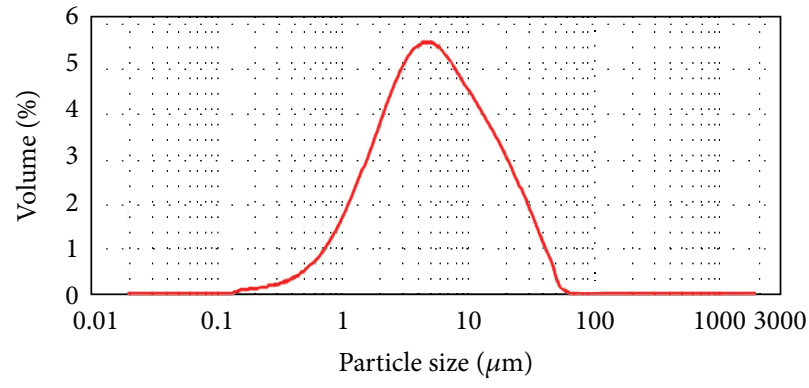

Figure 4: Particle size distribution of as-prepared $\mathrm{BaFe}_{12} \mathrm{O}_{19}$ powder.

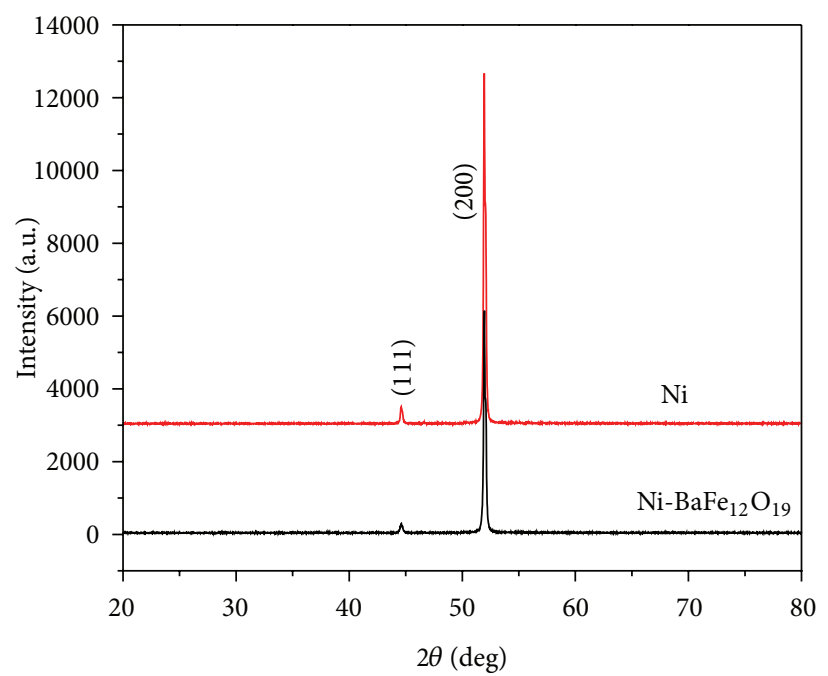

FIGURE 5: XRD patterns of electrodeposited (a) $\mathrm{Ni}$ and (b) Ni$\mathrm{BaFe}_{12} \mathrm{O}_{19}$ composite coatings.

where $b_{a}$ and $b_{c}$ are the Tafel slopes or the Tafel constants, expressed in $\mathrm{mV} / \mathrm{dec}$.

Corrosion rates $(\mathrm{CR})$ were calculated by the following equation:

$$
\mathrm{CR}=\frac{1.13 i_{\text {corr }} \times \text { Eq. wt. of } \mathrm{Ni}}{\text { Density of } \mathrm{Ni}} .
$$




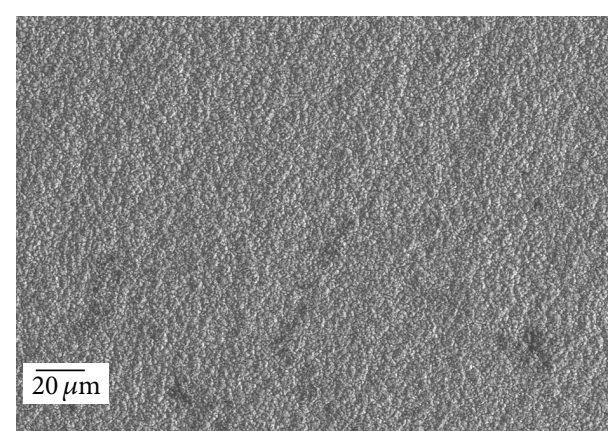

(a)

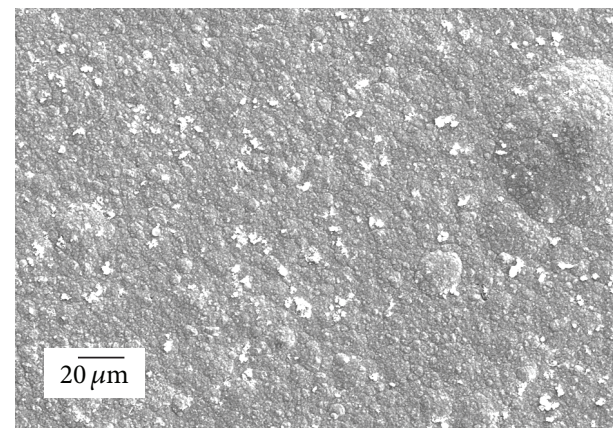

(c)

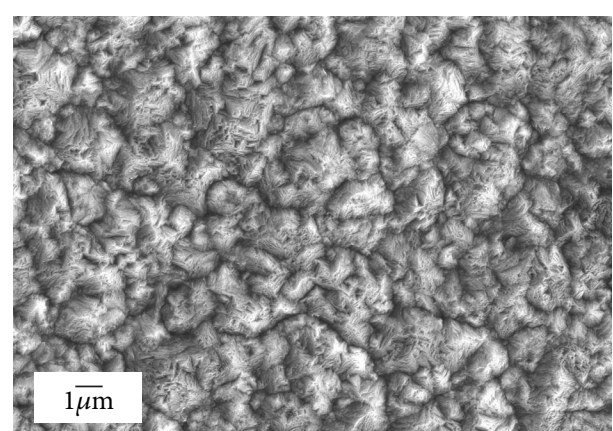

(b)

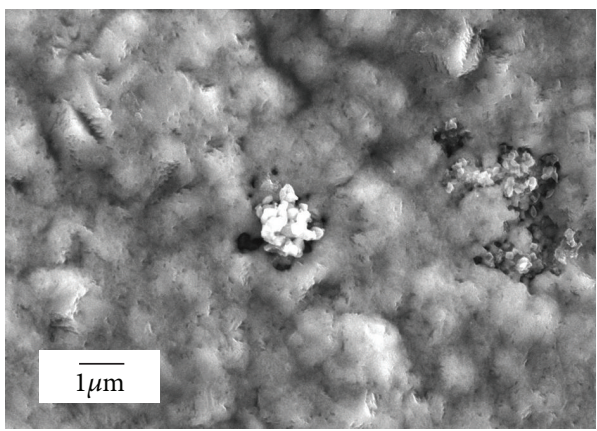

(d)

FIgURE 6: Surface FESEM images of electrodeposited (a-b) $\mathrm{Ni}$ and (c-d) $\mathrm{Ni}-\mathrm{BaFe}_{12} \mathrm{O}_{19}$ composite coatings.

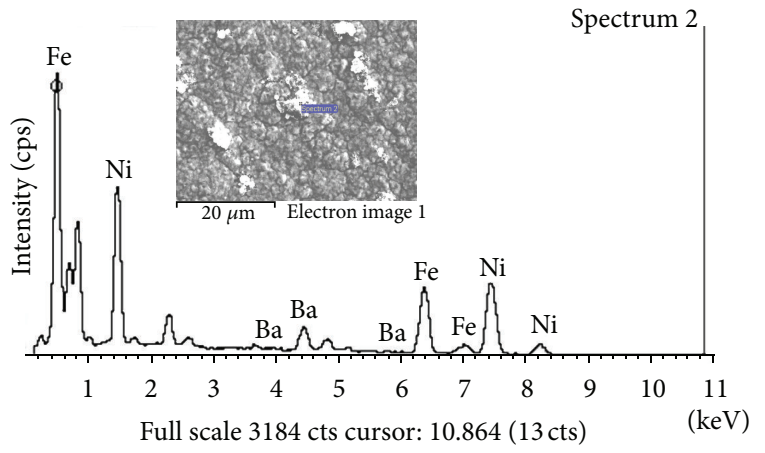

FIGURE 7: EDAX spectra recorded on the surface of electrodeposited $\mathrm{Ni}-\mathrm{BaFe}_{12} \mathrm{O}_{19}$ composite coating.

\section{Results and Discussion}

3.1. Powder Characterization. The as-prepared $\mathrm{BaFe}_{12} \mathrm{O}_{19}$ powder was poorly crystalline as seen from the XRD pattern (Figure 2).

And hence it was not possible to determine the crystallite size. However, the phase purity of the sample was indirectly evident from the strong magnetic behavior of the as-prepared $\mathrm{BaFe}_{12} \mathrm{O}_{19}$ powder (Figure 1). Further calcinations of the barium ferrite will result in crystalline powder as reported in the literature [8].

The powder morphology of the combustion synthesized barium ferrite powder was analyzed by field emission scanning electron microscopy (FESEM) (Figure 3). From the
FESEM image, it is evident that the particles are forming flakes and some hexagonal shaped particles mostly in nanosize were observed.

The particle size analysis of $\mathrm{BaFe}_{12} \mathrm{O}_{19}$ powder prepared by solution combustion method is shown in Figure 4 . The particles have a tendency to agglomerate, and this is evident from the particle size analysis. The particle size distribution curve showed a Gaussian distribution with an average agglomerated particle size of $5.3 \mu \mathrm{m}$.

3.2. $\mathrm{Ni}$ - $\mathrm{BaFe}_{12} \mathrm{O}_{19}$ Composite Coating. The XRD patterns of $\mathrm{Ni}$ and $\mathrm{Ni}-\mathrm{BaFe}_{12} \mathrm{O}_{19}$ electrocomposite coatings are shown in Figure 5, and the peaks were very sharp in case of plain Ni. The XRD patterns show the peaks corresponding to plain $\mathrm{Ni}$, and no peaks corresponding to $\mathrm{BaFe}_{12} \mathrm{O}_{19}$ were observed as the percentage of particles incorporated is less than $5 \mathrm{wt} \%$ and also due to the poorly crystalline nature of the powder. Also, there was no change in the orientation of $\mathrm{Ni}$ peaks with the particle incorporation.

FESEM images of electrodeposited plain $\mathrm{Ni}$ and $\mathrm{Ni}$ $\mathrm{BaFe}_{12} \mathrm{O}_{19}$ composite coating surfaces are shown in Figure 6. From the figure, it is evident that the barium ferrite particles are uniformly distributed throughout the Ni matrix (Figure 6(c)), and with the incorporation of the particles, there is a change in the shape of the nickel grains.

The energy dispersive X-ray analysis (EDAX) spectra recorded on the surface of the coatings confirmed the incorporation of barium hexaferrite particles in the coating (Figure 7). The weight percentage of $\mathrm{Ni}, \mathrm{Fe}, \mathrm{Ba}$, and $\mathrm{O}$ were 


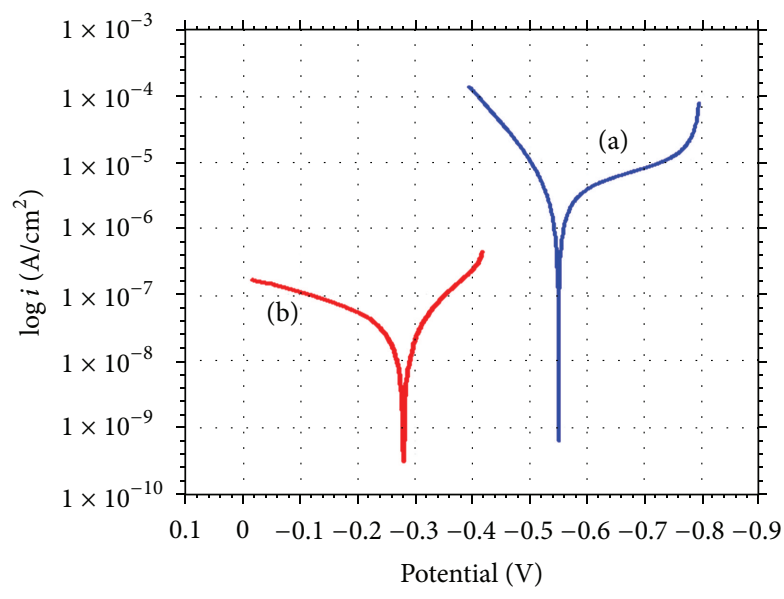

FIGURE 8: Tafel plots of electrodeposited (a) plain $\mathrm{Ni}$ and (b) Ni$\mathrm{BaFe}_{12} \mathrm{O}_{19}$ coatings.

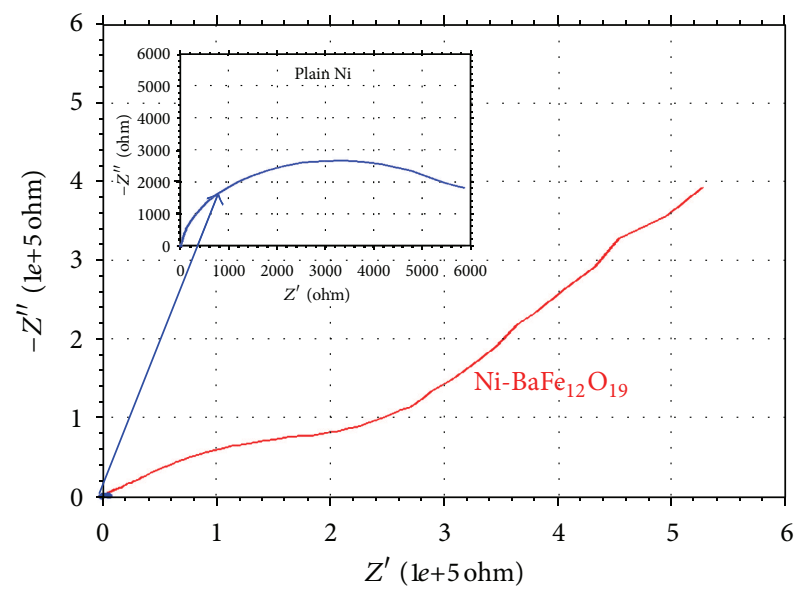

FIGURE 9: Nyquist plots of electrodeposited plain $\mathrm{Ni}$ (inset) and $\mathrm{Ni}$ $\mathrm{BaFe}_{12} \mathrm{O}_{19}$ coatings.

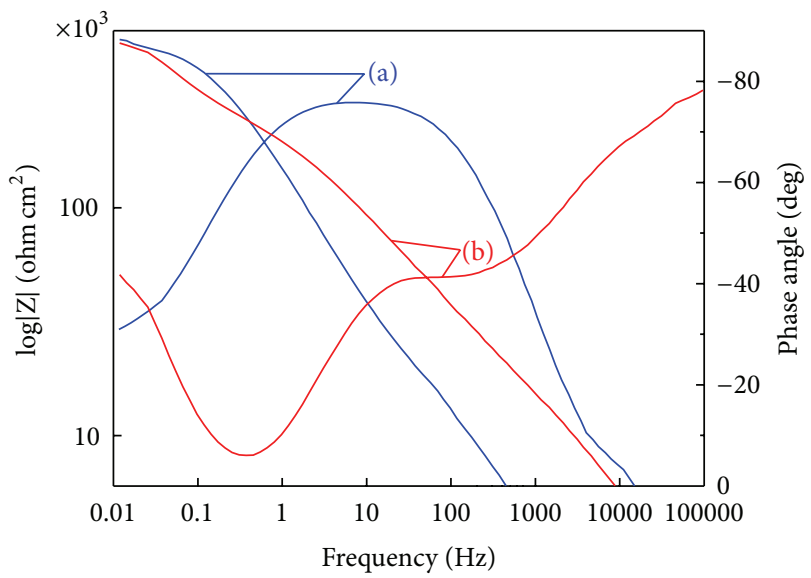

Figure 10: Bode plots of electrodeposited (a) Ni and (b) Ni$\mathrm{BaFe}_{12} \mathrm{O}_{19}$ coatings.
$31.71,18.28,9.41$, and $40.59 \%$, respectively, on a particular spot where white particles were seen.

The nanohardness values obtained from Oliver Pharr method on the cross-sections of the electrodeposited $\left(1.55 \mathrm{~A} \mathrm{dm}^{-2}\right) \mathrm{Ni}$ and $\mathrm{Ni}-\mathrm{BaFe}_{12} \mathrm{O}_{19}$ coating surface $s$ were $517 \pm 38 \mathrm{HV}$ and $777 \pm 16 \mathrm{HV}$, respectively. The improved hardness may be attributed to the dispersion strengthening of the Ni matrix due to the incorporation of barium hexaferrite particles.

The Tafel plots obtained for $\mathrm{Ni}$ and $\mathrm{Ni}-\mathrm{BaFe}_{12} \mathrm{O}_{19}$ coatings in $3.5 \mathrm{wt} \% \mathrm{NaCl}$ are shown in Figure 8. The corrosion potential $\left(E_{\text {corr }}\right)$, corrosion current $\left(i_{\text {corr }}\right)$, and polarization resistance $\left(R_{p}\right)$ obtained from the Tafel plots are listed in Table 1. From the Tafel plots, it is clear that $\mathrm{Ni}-\mathrm{BaFe}_{12} \mathrm{O}_{19}$ coating shows nobler behavior compared to plain Ni coating. Corrosion potential and corrosion current are lower for $\mathrm{Ni}$ $\mathrm{BaFe}_{12} \mathrm{O}_{19}$ compared to $\mathrm{Ni}$. This shows that, by incorporating $\mathrm{BaFe}_{12} \mathrm{O}_{19}$ particles in Ni matrix, the corrosion resistance of Ni can be enhanced (Table 1).

The Nyquist impedance plots for $\mathrm{Ni}$ and $\mathrm{Ni}-\mathrm{BaFe}_{12} \mathrm{O}_{19}$ obtained in free-air (nonaerated) condition in $3.5 \% \mathrm{NaCl}$ solution are shown in Figure 9. At higher frequencies, interception with the real axis is ascribed to the electrolyte bulk resistance $\left(R_{s}\right)$, and at low frequencies an interphase appears whose interception with the real axis is ascribed to the charge transfer resistance $\left(R_{\mathrm{ct}}\right)$. In case of $\mathrm{Ni}-\mathrm{BaFe}_{12} \mathrm{O}_{19}$, additional Warburg diffusion behavior was observed at low frequency region, which represents a kind of resistance to mass transfer. A Warburg diffusional phenomenon, which suggests diffusion-controlled mechanism in the corrosion reaction, was observed in the low frequency region for $\mathrm{Ni}-\mathrm{BaFe}_{12} \mathrm{O}_{19}$ coating. The Warburg impedance is usually observed at low frequencies in electrochemical experiments due to the concentration polarization induced by a sluggish diffusion process [9]. The Warburg impedance can occur due to the following two reasons: (i) if there is some porosity/cracks in the coating the electrolyte can enter through the pores and attack the substrate, and in turn the corrosion products can block the pores and further offer resistance to the electrolyte; (ii) some loosely held particles may be dislodged in the electrolyte, and thereby exposing the substrate to the electrolyte. However, cracks and pores were not seen in the FESEM images of as-prepared coating surface.

The Bode plot of Ni showed a distinct single peak corresponding to the electrode/electrolyte interface compared to $\mathrm{Ni}-\mathrm{BaFe}_{12} \mathrm{O}_{19}$ (Figure 10). In both equivalent circuits, the double layer capacitance $C_{\mathrm{dl}}$ is represented by a constant phase element $(Q)$, which accounts for the deviation from the ideal dielectric behavior of the nonideal capacitor. The $R_{\mathrm{ct}}$ value of $\mathrm{Ni}$ was about $7 \mathrm{k} \Omega \mathrm{cm}^{-2}$, and for $\mathrm{Ni}-\mathrm{BaFe}_{12} \mathrm{O}_{19}$ it was $1081 \mathrm{k} \Omega \mathrm{cm}^{-2}$. It is gratifying to note that there is a good correlation between the $R_{\mathrm{p}}$ and $R_{\mathrm{ct}}$ values. This shows that the corrosion resistance of $\mathrm{Ni}-\mathrm{BaFe}_{12} \mathrm{O}_{19}$ is higher than that plain Ni. The higher $R_{\mathrm{ct}}$ value of $\mathrm{Ni}-\mathrm{BaFe}_{12} \mathrm{O}_{19}$ indicates that the active area available for the corrosion attack is less when compared to Ni.

The phase angle versus log (frequency) shows that phase angle of both $\mathrm{Ni}$ and $\mathrm{Ni}-\mathrm{BaFe}_{12} \mathrm{O}_{19}$ coatings was less than $90^{\circ}$ indicating their lower capacitive behavior. The $n$ value for $\mathrm{Ni}$ 


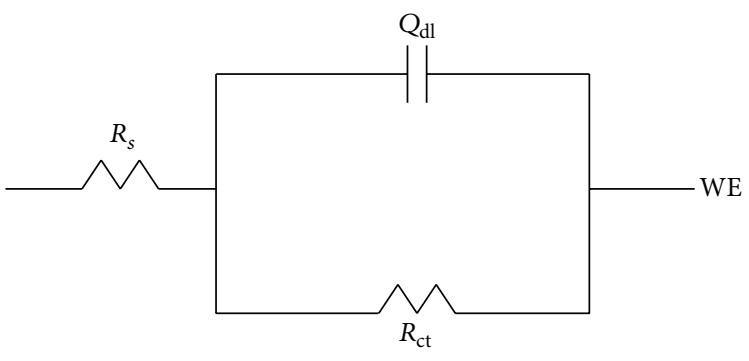

(a)

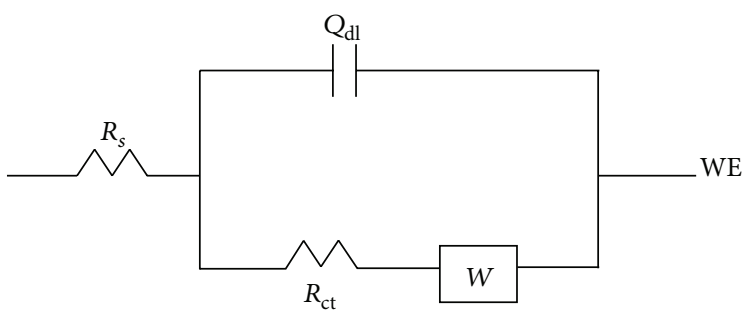

(b)

FIgURE 11: (a): Equivalent circuit used to fit the parameters of nickel $\left(R_{s}\right.$ : solution resistance; $Q_{\mathrm{dl}}$ : double layer capacitance; $R_{\mathrm{ct}}$ : charge transfer resistance; WE: working electrode). (b): Equivalent circuit used to fit the parameters of Ni- $\mathrm{BaFe}_{12} \mathrm{O}_{19}$ composite coating $\left(R_{s}\right.$ : solution resistance; $Q_{\mathrm{dl}}$ : double layer capacitance; $R_{\mathrm{ct}}$ : charge transfer resistance; W: Warburg impedance; WE: working electrode).

TABLE 1: Corrosion potential, corrosion rates, and Tafel slopes calculated from potentiodynamic diagrams for mild steel, pure $\mathrm{Ni}$, and $\mathrm{Ni}-\mathrm{BaFe}_{12} \mathrm{O}_{19}$.

\begin{tabular}{lccccc}
\hline Coating & $\begin{array}{c}i_{\text {corr }} \\
\left(\mu \mathrm{A} / \mathrm{cm}^{2}\right)\end{array}$ & $\begin{array}{c}E_{\text {corr }} \\
(\mathrm{V})\end{array}$ & $\begin{array}{c}b_{c} \\
(\mathrm{~V} / \mathrm{dec})\end{array}$ & $\begin{array}{c}b_{a} \\
(\mathrm{~V} / \mathrm{dec})\end{array}$ & $\begin{array}{c}R_{P} \\
\left(\mathrm{k} \Omega \mathrm{cm}^{2}\right)\end{array}$ \\
\hline $\mathrm{Ni}$ & 3.61 & -0.551 & 0.031 & 0.114 & 8.29 \\
$\mathrm{Ni}-\mathrm{BaFe}_{12} \mathrm{O}_{19}$ & 0.034 & -0.279 & 0.2615 & 0.1262 & 1087.67 \\
\hline
\end{tabular}

TABLE 2: Electrochemical impedance analysis data.

\begin{tabular}{|c|c|c|c|c|c|}
\hline Sample & $\begin{array}{c}R_{\mathrm{s}} \\
\left(\Omega \mathrm{m}^{2}\right)\end{array}$ & $\begin{array}{c}Q_{\mathrm{dl}}-Y_{0} \\
\left(\mu \mathrm{F} / \mathrm{cm}^{2}\right)\end{array}$ & $n_{\mathrm{dl}}$ & $\begin{array}{c}R_{\mathrm{ct}} \\
\left(\mathrm{k} \Omega \mathrm{cm}^{2}\right)\end{array}$ & $\begin{array}{c}W \\
\left(\mu \Omega \mathrm{cm}^{-2} \mathrm{~s}^{-1 / 2}\right)\end{array}$ \\
\hline $\mathrm{Ni}$ & 1.05 & 226.1 & 0.83 & 7.03 & - \\
\hline $\mathrm{Ni}-\mathrm{BaFe}_{12} \mathrm{O}_{19}$ & 1.12 & 2.74 & 0.37 & 1081 & 9.9 \\
\hline
\end{tabular}

coating was higher than that of $\mathrm{Ni}-\mathrm{BaFe}_{12} \mathrm{O}_{19}$ which indicates a higher capacitive behavior. The corrosion rates as calculated from (3) were $1.34 \times 10^{-6}$ and $1.2 \times 10^{-7} \mathrm{~g} / \mathrm{h}$, respectively, for $\mathrm{Ni}$ and $\mathrm{Ni}-\mathrm{BaFe}_{12} \mathrm{O}_{19}$ composite coatings.

The equivalent circuit shown in Figure 11(a) was used to fit the parameters of plain $\mathrm{Ni}$, and the fitted values are tabulated in Table 2. The appropriate equivalent circuit was used for fitting the parameters of $\mathrm{Ni}-\mathrm{BaFe}_{12} \mathrm{O}_{19}$, and the acquired data are shown in Figure 11(b).

\section{Conclusions}

Barium hexaferrite particles having magnetic property prepared by the solution combustion method were incorporated in the Ni-metal matrix. The bath loading beyond $5 \mathrm{~g} / \mathrm{L}$ was not possible due to the very fine nature of the combustion synthesized powder. It was gratifying to note that the anticorrosion properties of the Ni matrix could be further improved by the incorporation of hard $\mathrm{BaFe}_{12} \mathrm{O}_{19}$ particles in the Ni matrix. Corrosion potential and corrosion current were lower for $\mathrm{Ni}-\mathrm{BaFe}_{12} \mathrm{O}_{19}$ when compared to Ni. There was an increase in the nanohardness of the $\mathrm{Ni}$-composite coating with the incorporation of $\mathrm{BaFe}_{12} \mathrm{O}_{19}$ particles. The $R_{\mathrm{ct}}$ value of Ni was about $7 \mathrm{k} \Omega \mathrm{cm}^{-2}$, and for $\mathrm{Ni}-\mathrm{BaFe}_{12} \mathrm{O}_{19}$ it was $1081 \mathrm{k} \Omega \mathrm{cm}^{-2}$. This shows that the incorporation of barium hexaferrite particles enhances the corrosion resistance of $\mathrm{Ni}$ $\mathrm{BaFe}_{12} \mathrm{O}_{19}$ coating.

\section{Acknowledgments}

The authors thank the Director of CSIR-NAL for his encouragement and SIP-SED-02 project for the funding. The authors thank Mr. Siju and Mr. Praveen for the FESEM and nanohardness measurements.

\section{References}

[1] I. Garcia, J. Fransaer, and J. P. Celis, "Electrodeposition and sliding wear resistance of nickel composite coatings containing micron and submicron SiC particles," Surface and Coatings Technology, vol. 148, no. 2-3, pp. 171-178, 2001.

[2] C. T. J. Low, R. G. A. Wills, and F. C. Walsh, "Electrodeposition of composite coatings containing nanoparticles in a metal deposit," Surface and Coatings Technology, vol. 201, no. 1-2, pp. 371-383, 2006.

[3] J. Niedbała, A. Budniok, and E. Łagiewka, "Hydrogen evolution on the polyethylene-modified Ni-Mo composite layers," Thin Solid Films, vol. 516, no. 18, pp. 6191-6196, 2008.

[4] J. K. Dennis and T. E. Such, Nickel and Chromium Plating, Woodhead Publishing, 3rd edition, 1993.

[5] X. Sui, M. Scherge, M. H. Knyder, J. E. Snyder, V. G. Harris, and N. C. Koon, "Barium ferrite thin-film recording media," Journal of Magnetism and Magnetic Materials, vol. 655, no. 1-3, pp. 132139, 1996.

[6] S. Guan and B. J. Nelson, "Magnetic composite electroplating for depositing micromagnets," Journal of Microelectromechanical Systems, vol. 15, no. 2, pp. 330-337, 2006.

[7] N. S. Qu and F. Jiao, "Fabrication of CoNiMnP-BaFe ${ }_{12} \mathrm{O}_{19}$ nanocomposite coatings by electrodeposition," Transactions of the Institute of Metal Finishing, vol. 90, no. 2, pp. 92-97, 2012.

[8] K. Suresh and K. C. Patil, "A Recipe for an instant synthesis of fine particle oxide materials"' in Perspectives in Solid State Chemistry, K. J. Rao, Ed., pp. 376-388, Narosa Publishing House, New Delhi, India, 1995.

[9] J. S. Yoo and S. M. Park, "Reply to comments on the article 'an electrochemical impedance measurement techniques employing fourier transform,' Analytical Chemistry, vol. 73, no. 16, pp. 4060-4061, 2001. 

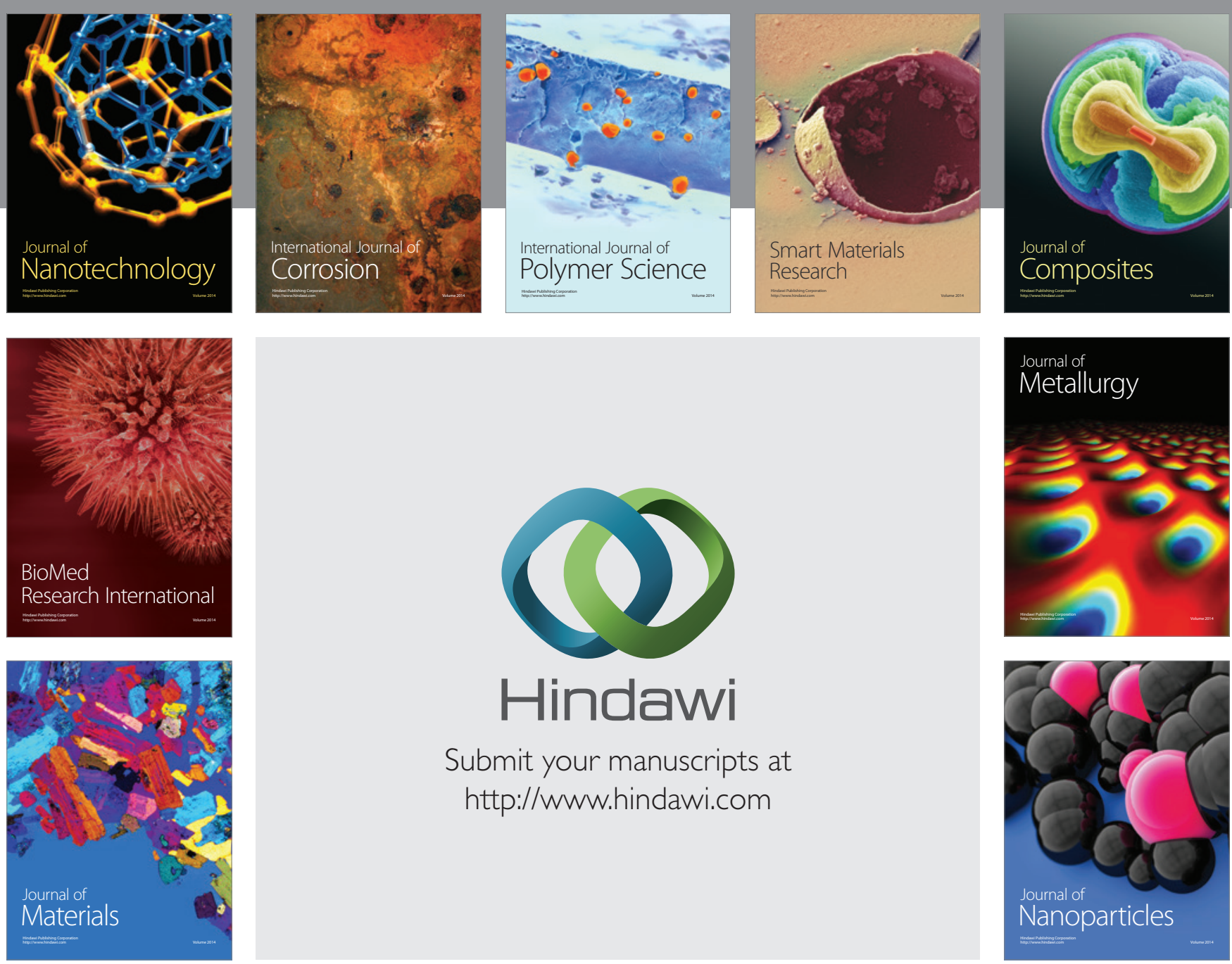

Submit your manuscripts at http://www.hindawi.com
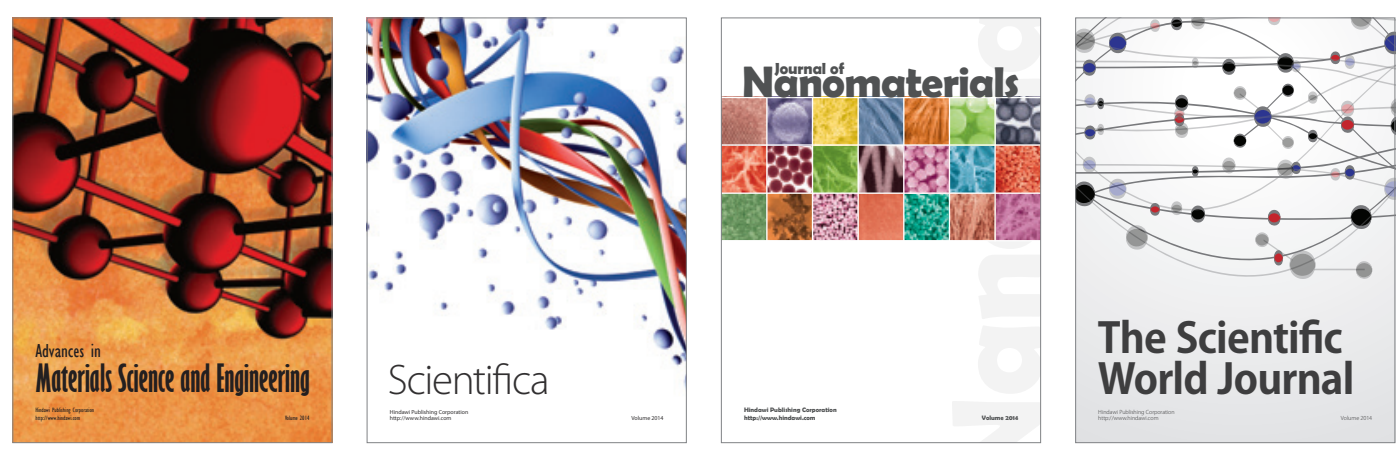

\section{The Scientific World Journal}
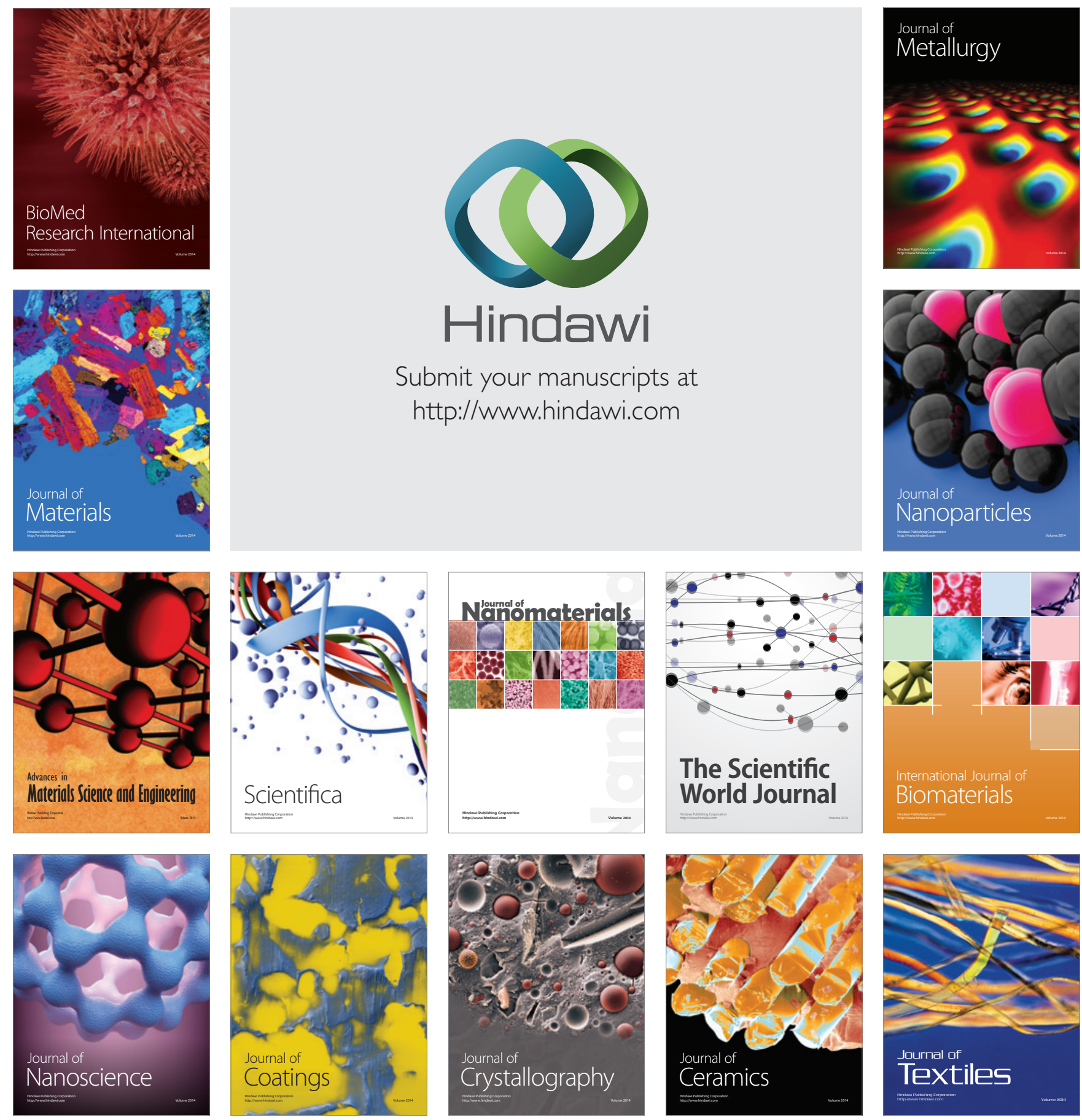